УДК 378.1

DOI:

Тетяна Мастеркова, викладач кафедри суспільно-гуманітарних дисииплін Комунального закладу “Житомирський ОІППО” Житомирської обласної ради

\title{
ПРОФЕСІЙНА КОМПЕТЕНТНІСТЬ: СУЧАСНІ ФОРМАТИ ПОШИРЕННЯ ПЕДАГОГІЧНОГО ДОСВІДУ ТА МЕТОДИЧНИХ РОЗРОБОК
}

У статті представлено сучасні підходи до способів узагальнення власного досвіду педагога, поширення професійних досягнень, самопрезентації педагогічної діяльності в результаті неперервного супроводу методичними структурами та створення необхідних умов, які сприяють формуванню у кожного вчителя потреб до саморозвитку у конкретному виді педагогічної діяльності. Розвиток компетентності фахівия полягає у формуванні в нього системи знань і особистісних якостей, необхідних для виконання різних функиій професійної діяльності. Охарактеризовано можливості реалізації потенціалу педагога на основі саморозвитку.

Ключові слова: професійна компетентність; професіоналізм; самовдосконалення; самоосвіта; саморозвиток; траєкторія професійного розвитку педагогічних прачівників; професійні спільноти.

Puc. 1. Лim. 10.

Tatyana Masterkova, Lecturer of the Social and Humanitarian Disciplines Department, Communal Educational Institution “Zhytomyr Regional in-Service Teachers Training Institute” Zhytomyr Regional Council

\section{PROFESSIONAL COMPETENCE: MODERN FORMATS FOR DISSEMINATION OF PEDAGOGICAL EXPERIENCE AND METHODOLOGICAL DEVELOPMENTS}

The article presents the modern approaches to ways of generalizing the teacher's own experience, dissemination of professional achievements, self-presentation of pedagogical activities as a result of continuous support of methodological structures and creation of necessary conditions that contribute to the formation of each teacher's needs for self-development.

The development of the competence of the specialist is to form in him a system of knowledge and personal qualities necessary to perform various functions of professional activity, as an opportunity to realize the potential of the teacher on the basis of self-development. At the same time, it is a dynamic process of "unfolding " the qualities of the teacher's personality, which are manifested in the formation of interest in pedagogical activities, in mastering professionally important and socially significant personality qualities.

The process of self-realization of the teacher's personality begins with professional self-determination. The result of the teacher's self-realization should be the formed need for continuous self-improvement. The creation of an effective management system for the development of professional suitability of teachers is determined by the task of the current methodological structures of institutions of postgraduate pedagogical education and the newly established Centers for Professional Development of Teachers. The system is aimed at creating conditions for successful professional development, professional self-preservation of the teacher, and practical confirmation of the criteria of his professional productivity, professional identity and professional maturity.

The situation of success can be an impetus for further development of the teacher, and personal needstimulates the setting of appropriate goals and methods of implementation. Pedagogical success - the concept is ambiguous, on the one hand it is the optimal relationship between own expectations and the results of the activities performed by the individual; on the other hand - it is a feeling of joy, satisfaction with the result, the goal achieved. This feeling will be the basis for the formulation of new goals, self-assessment of the level of professional competence by a specialist.

Keywords: professional competence; professionalism; self-improvement; self-education; self-development; trajectory of professional development of pedagogical workers; professional communities.

$\Pi$ остановка проблеми. Актуальність проблеми зумовлена необхідністю вдосконалення напрямів і змісту професійної діяльності педагога відповідно до вимог Професійного стандарту за професіями "Вчитель початкових класів закладу загальної середньої освіти”, "Вчитель закладу загальної середньої освіти”, “Вчитель 3 початкової освіти закладу загальної середньої освіти (з дипломом молодшого спеціаліста)", затвердженого наказом Мінекономіки від 23.12.2020 р. № 2736, яким передбачене здійснення вчителем самопрезентації власного досвіду, поширення практик, демонстрації ресурсів, надання іншим педагогам методичної допомоги у плануванні та організації освітнього процесу [7]. 


\section{ПРОФЕСІЙНА КОМПЕТЕНТНІСТЬ: СУЧАСНІ ФОРМАТИПОШИРЕННЯ ПЕДАГОГІЧНОГО ДОСВІДУ ТА МЕТОДИЧНИХ РОЗРОБОК}

Готовність сучасного педагога до вдосконалення професійної компетентності значною мірою залежить від його вмотивованості до саморозвитку. Саморозвиток-внутрішній процес, визначений спосіб реагування людини на вплив середовища, усвідомлене самовдосконалення.

Аналіз останніх досліджень і публікацій. У дослідженнях Т.Горохівської, С.Кузікової,В.Лозовецької, А. Смолюка, В. Ямницького охарактеризовано саморозвиток педагога, як обов'язкової складової сучасної освіти, показника суб'єктності вчителя на всіх етапах його неперервної педагогічної освіти $[1 ; 3 ; 4 ; 8 ; 10]$. Перехід до парадигми самоосвіти та саморозвитку особистості реалізує можливість для інформаційної взаємодії різноманітними способами, співпраці всіх суб'єктів освітнього процесу на основі використання потужного потенціалу інформаційнокомунікаційних технологій $[9,202]$.

Мета дослідження полягає у систематизації та обгрунтуванні сучасних шляхів представлення вчителем, як суб'єкта інноваційних процесів в контексті саморозвитку, методичних розробок, власних напрацювань, досвіду.

Завдання статті:

- узагальнення підходів до збору та аналізу професійних досягнень відповідно до вимог професійних стандартів;

- виявлення труднощів у прагненні педагогів до самовдосконалення, пошук оптимальних шляхів їх подолання;

- практики оприлюднення власного педагогічного досвіду з використанням можливостей цифрових технологій.

Виклад основного матеріалу. Узагальнення й опис власного педагогічного досвіду достатньо важливе та складне завдання. На сьогодні для атестації, участі в різних конкурсах, обміну досвідом педагогу важливо навчитися здійснювати рефлексію власних професійних досягнень, вмінь, напрацювань. Педагогічний досвід - це шкала виміру ефективності діяльності фахівця, тобто рівень професійної компетентності, який дає змогу досягати оптимальних результатів в освітньому процесі при порівняно незначних витратах сил і часу. Ефективність є рівнем досягнень запланованої педагогічної мети неперервного розвитку фахівця.

Підгрунтям саморозвитку є потреба людини в нових досягненнях, прагнення до успіху, до вдосконалення, активна життєва позиція, позитивне мислення, віра у свої можливості, розуміння сенсу життя. Специфіка самовдосконалення як фактора саморозвитку особистості полягає у тому, що серед усіх інших чинників цей найбільше спирається на індивідуальні властивості особистості, їі потреби та нахили. Завдяки цьому людині вдається самостійно виявити свої домінуючі задатки, які у майбутньому можуть бути визначальними при виборі життєвого шляху, забезпечувати саморозвиток фізичних, інтелектуальних та емоційно-вольових якостей.

Виникнення свідомого прагнення до саморозвитку $\epsilon$ наслідком попереднього зовнішнього розвитку, тобто впливу суспільства на особистість через суб'єктивну діяльність вихователів, батьків, вчителів тощо. Саморозвиток і самовдосконалення взаємопов'язані з процесом самореалізації педагога, тобто процесом самостійного розв'язання конкретних, значущих педагогічних завдань. Відтак створення програми власного професійного саморозвитку є реалізацією переходу від усвідомленої потреби до реальної діяльності, що призводить до самовдосконалення вчителя і передбачає формулювання нових цілей, визначення нових шляхів, засобів і методів необхідних для виконання діяльності. На шляху програмування саморозвитку багато залежить від вміння особистістю реалізувати життеві домагання.

Учитель - основна дійова особа у реформуванні сучасної освіти. Змінюються орієнтири освіти - змінюється й сам вчитель, змінюється мета й завдання його освітянської діяльності.

Так, у новому Законі України “Про освіту” (ст. 59) зазначено, що професійний розвиток педагогічних працівників передбачає постійну самоосвіту, участь у програмах підвищення кваліфікації та будь-які інші види і форми професійного зростання [2].

Зазначимо, що раніше система освіти була спрямована на тривалу, грунтовну трансляцію знань від учителя до учня. Сучасний процес передачі знань $є$ багатовекторним “від усіх i всюди”, а вчитель має стати партнером для учня у формуванні ключових компетентностей. Саме така освітня взаємодія передбачена положеннями Концепції "Нова українська школа" [5].

Водночас вимогами Професійного стандарту “Вчитель початкових класів закладу загальної середньої освіти”, "Вчитель закладу загальної середньої освіти”, “Вчитель $з$ початкової освіти закладу загальної середньої освіти” передбачено володіння вчителем необхідними компетентностями для здійснення самопрезентації власного досвіду, поширення практик, демонстрації ресурсів, надання іншим педагогам методичної допомоги у плануванні й організації освітнього процесу [7]. Окрім того, серед вимог до професійних і 
особистісних якостей освітян, нормативні документи визначають вмотивованість, компетентність, творчість, гнучке мислення, відповідальність за результати власної діяльності та здатність до саморозвитку.

Також сучасний вчитель має можливість самостійно обирати зміст i форму самопрезентації, визначати особливості структурування, збору й накопичення матеріалів, перетворювати обов'язкову вимогу поширення власного досвіду на професійну потребу демонстрації кращих власних досягнень.

Зазначимо, що об'єктивна реальність пов'язана $з$ пандемією, зумовила практично всі установи освіти перейти на онлайн комунікацію. Розглядаючи онлайн взаємодію Центрів професійного розвитку педагогічних працівників 3 практикуючими вчителями відзначаємо, що в сучасній педагогічній науці відсутні напрацювання системного аналізу щодо цифрового представлення професійного досвіду педагогом.

У загальному вигляді, оприлюднення сучасного педагогічного досвіду визначаємо як спосіб організації процесу представлення систематизованих матеріалів в освітньому середовищі з використанням можливостей мережі Інтернет та мультимедіа.

Онлайн формат самопрезентації дає можливість “масштабувати” досвід найкращих вчителів на всю країну і створює умови для взаємонавчання, поширення кращих практик тощо. Саме такий підхід до організації професійного зростання педагогічних працівників визначений пріоритетним у діяльності Центру професійного розвитку педагогів м. Бердичів Житомирської області.

Основною метою створених центрів професійного розвитку педагогів відповідно Положення, визначено сприяння професійному розвитку педагогічних працівників, їх психологічній підтримці та консультуванню [6]. Тому їх діяльність передбачає узагальнення, поширення інформації з питань професійного розвитку педагогічних працівників, координація діяльності професійних спільнот, формування й оприлюднення на бази даних програм підвищення кваліфікації, інші джерела інформації, необхідні для професійного розвитку педагогічних працівників.

Центри організовують консультування педагогічних працівників з питань планування та визначення траєкторії їх професійного розвитку, проведення супервізії, особливостей організації освітнього процесу за різними формами здобуття освіти, у тому числі з використанням дистанційних технологій навчання, впровадження компетентнісного, особистісно орієнтованого, діяльнісного, інклюзивного підходів до навчання здобувачів.

Колектив Центру професійного розвитку педагогів м. Бердичів прагне створити належні умови для активного обміну ідеями та освітніми практиками, взаємодії та партнерства, разом з педагогами громади розбудовувати професійне синергетичне середовище, яке надихало б та мотивувало до професійного зростання. Нова сучасна та дієва модель спілкування, сприятлива психологічна атмосфера забезпечують результативну співпрацю з педагогами. Центр прагне відповідати потребам кожного педагога, конкретним професійним запитам.

Створена інформаційна сторінка на сайті управління освіти і науки виконавчого комітету Бердичівської міської ради складається з семи розділів, що вміщують актуальну інформацію для педагогів та керівників закладів освіти, а також онлайн-замовлення необхідних консультацій. Зокрема, "Про нас", "Нормативна база", "Підвищення фахового рівня”, “Атестація”, “Сертифікація”, “Інституційний аудит”, “Дистанційне навчання”, “Замовлення консультацій”, "Рекомендації щодо підвищення кваліфікації'

Справжнім комунікативним майданчиком для педагогічної громади стало створення сторінки Центру у соціальній мережі Facebook. Щоденні публікації серед яких інформаційно-методичні матеріали, актуальна інформація щодо діяльності міських професійних спільнот педагогів, професійного розвитку педагогічних працівників, можливостей підвищення кваліфікації, методичні цікавинки, творчі звіти педагогів в ході підготовки до майбутньої атестації, тощо.

Зазначимо, що для організації якісної, адресної консультативної роботи Центру було проведене опитування серед педагогів міста (рис. 1). Сьогодні час створюється сучасна модель спілкування через залучення педагогів до участі у професійних спільнотах, вивчення їх запитів та очікувань (http://bit.do/fPZJP).

Таким чином, основна мета Центру - донести до вчителів інформацію, яка в один клік допоможе у роботі, зробить підготовку до уроків, занять та позакласних заходів зручною та динамічною, відкриє нові можливості. Це забезпечує процес відкритості безмежного потенціалу освіти, знайомство з останніми новинами, сприяє розвитку творчої ініціативи і академічної свободи, виявленню рівня педагогічної компетентності.

Педагогічна компетентність вчителя комплекс якостей особистості, що забезпечує високий рівень самоорганізації професійної 


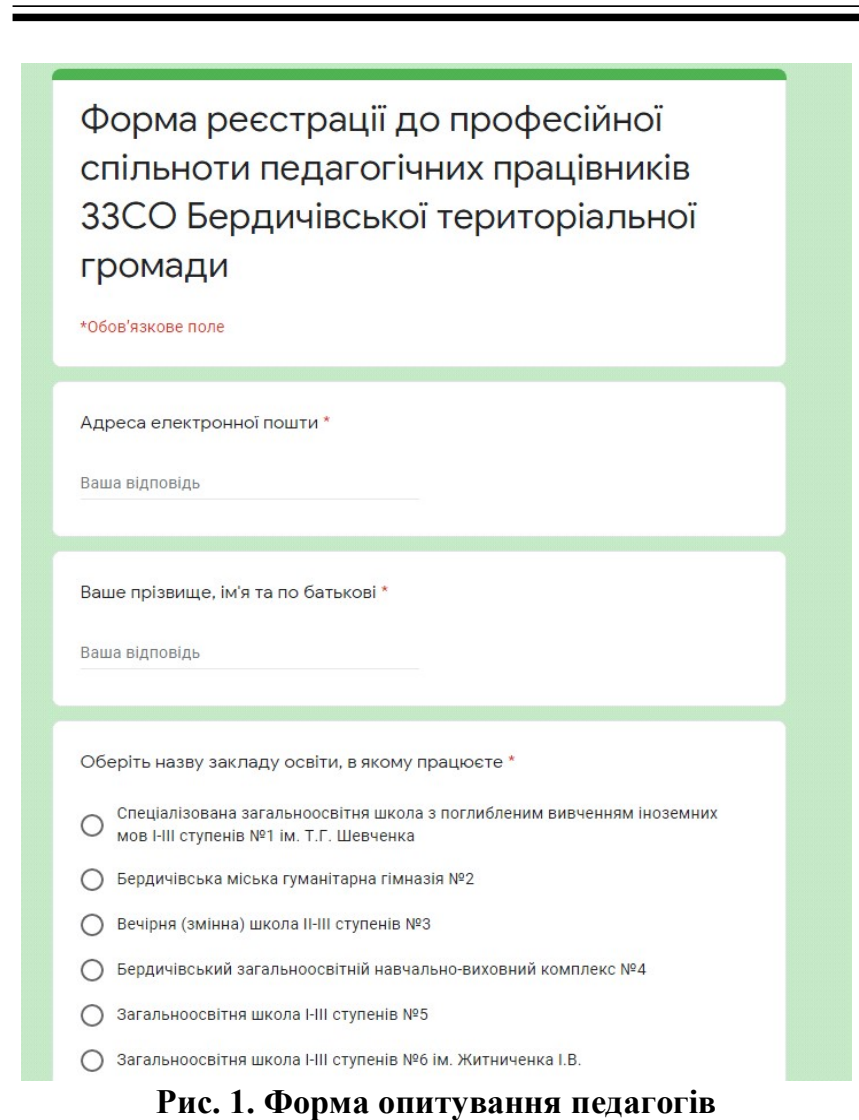

Рис. 1. Форма опитування педагогів

діяльності та їі результативності. Створення особистісноорієнтованої моделі підвищення кваліфікації учителя, розвиток його творчих можливостей лежить в основі роботи методичної служби. Важливу роль у реалізації цих завдань відіграє моніторинг професійної компетентності педагогічних працівників та інноваційні підходи щодо керівництва самоосвітньою діяльністю вчителів.

Від початку 2021 р. Центром організовано проведення атестаційного марафону у дистанційному форматі. Вперше із професійними напрацюваннями педагогів змогли ознайомитися не тільки члени експертних груп, атестаційних комісій, але і широке коло педагогічної громадськості міста. Кожен учасник марафону прагнув створити власний професійний імідж, презентуючи творчі звіти, майстер-класи, відеоуроки, публікації, сайти, блоги.

Водночас на базі Комунального закладу “Житомирський обласний інститут післядипломної педагогічної освіти" Житомирської обласної ради запроваджено проект “Добрі практики”, де у форматі онлайн-семінарів кращі педагоги області мають змогу презентувати результати діяльності, напрацьований перспективний педагогічний досвід. Адже процес самопрезентації, самовизначення означає активний пошук можливого розвитку педагога, формування себе як учасника спільноти професіоналів. Тому така діяльність педагога не короткострокове явище, а тривалий процес самопізнання і саморозвитку, обов'язковий елемент становлення спеціаліста (http://bit.do/fQaDL; http:// bit.do/fQaDX; http://bit.do/fQaEg).

Таким чином, цей напрям діяльності Центру та КЗ “Житомирський ОІППО” ЖОР є перспективним для надання консультативної допомоги педагогам, що атестуватимуться за новим положенням про атестацію, а також для визначення майбутньої траєкторії їх професійного розвитку.

Висновки та пропозиції. Професійна здатність педагога до самопрезентації свідчить про сформованість особистісного контуру регулювання процесу професійного розвитку, про ступінь усвідомлення співвідношення спеціалістом фахових можливостей і вимог, які висуваються до нього. Професійна зрілість $є$ провідним показником становлення суб'єкта професійної діяльності. Тому діяльність методичних структур щодо супроводу професійного становлення педагога має розвиватися як система заходів, спрямованих на створення умов для успішного розвитку особистості, навичок забезпечення педагогічного професійного самозбереження, задоволення власною діяльністю, попередження професійного самовигорання.

Перспективами подальших досліджень вбачалось вивчення досвіду діяльності педагогічних професійних спільнот щодо створення умов для супроводу та розвитку культури самопрезентації педагога. Адже базовими складовими становлення педагога $є$ етапи його професійного вдосконалення: від виникнення професійних намірів, прояву активного входження в професію, до повної реалізації особистості в професії.

\section{ЛIТЕРАТУРА}

1. Горохівська Т. Розвиток професійно-педагогічної компетентності викладачівфахових дисциплін технічних ЗВО в умовах післядипломної педагогічної освіти. Молодь і ринок. 2020. №3-4 (182-183). С. 98 103. URL: http://mir.dspu.edu.ua/article/view/216720/ $\underline{216751 /}$

2. Закон України “Про освіту”. Відомості Верховної ради України. 2019. №2657-VIII. 2661 - VIII. URL: https:/ zakon.rada.gov.ua/laws/show/2145-19 


\section{ПРОФЕСІЙНА КОМПЕТЕНТНІСТЬ: СУЧАСНІ ФОРМАТИ ПОШИРЕННЯ ПЕДАГОГІЧНОГО ДОСВІДУ ТА МЕТОДИЧНИХ РОЗРОБОК}

3. Кузікова С. Б. Феноменологія саморозвитку особистості: проблемне поле дослідження. Науковий вісник Миколаївського державного університету ім. В. О. Сухомлинського. Сер.: Психологічні науки. 2012. T. 2, Вип. 9. С. 145-149. URL: http://nbuv.gov.ua/UJRN/ Nvmdups $2012 \quad 2 \quad 9 \quad 30$.

4. Лозовецька В. Т. Концептуальні засади професійного саморозвитку сучасної особистості. Науковий вісник Інституту професійно-технічної освіти НАПН Украӥни. Професійна педагогіка: зб. наук. пращь. 2014. № 1. С. 33-39.

5. Міністерство освіти і науки України. 2016. Кониепція "Нова украӥнська школа". URL: https:// mon.gov.ua/storage/app/media/zagalna\%20serednya/ nova-ukrainska-shkola-compressed.pdf

6. Положення про центр професійного розвитку педагогічних працівників. Постанова Кабінету Міністрів України. 29.07.2020 p. № 672. URL: https:// zakon.rada.gov.ua/laws/show/672-2020-\%D0\%BF\#n10

7. Реєстр професійних стандартів. Сайт Мінекономіки. 2021. URL: https://www.me.gov.ua/ Documents/Detail?lang=uk-UA\&id=22469103-4e36-4d41b1bf-288338b3c7fa\&title=RestrProfesiinikhStandartiv

8. Смолюк А. I. Теоретична підготовка вчителя початкової школи у формуванні готовності до професійного саморозвитку. Актуальні проблеми педагогічної освіти: Свропейський і начіональний вимір. 2017. С. 253-256.

9. Фамілярська Л.Л. Неперервна освіта педагога: сутність сучасної взаємодії в освітньому середовищі. Актуальні питання, проблеми та перспективи розвитку гуманітарного знання у сучасному інформачійному просторі: начіональний та інтернаціональний аспекти: зб. наукових праџь. 2016 C. 200-202. URL: https://core.ac.uk/download/pdf/ 84594081.pdf\#page $=200$

10. Ямницький В. М. Здатність до саморегуляції як основа професіоналізації спеціаліста. Психологія. реальність і перспективи. 2013. Вип. 1. С. 26-29.

\section{REFERENCES}

1. Horokhivska, T. (2020). Rozvytok profesiinopedahohichnoi kompetentnosti vykladachivfakhovykh dystsyplin tekhnichnykh ZVO V umovakh pisliadyplomnoipedahohichnoi osvity [Development of professional and pedagogical competence of teachers of professional disciplines of technical free economic education in the conditions of postgraduate pedagogical education.]. Youth \& market. №3-4 (182-183). pp. 98103. Available at: http://mir.dspu.edu.ua/article/view/ 216720/216751/. [in Ukrainian].

2. Zakon Ukrainy "Pro osvitu" [Law of Ukraine "OnEducation”]. Available at: https://zakon.rada.gov.ua/ laws/show/2145-19/. [in Ukrainian]
3. Kuzikova, S. B. (2012). Fenomenolohiia samorozvytku osobystosti: problemne pole doslidzhennia [Phenomenology of personality self-development: a problem field of research]. Scientific Bulletin of Nikolaev State University. V.O. Sukhomlinsky. Psychological Sciences. Vol. 2, Issue. 9. pp. 145-149. Available at: http:/ /nbuv.gov.ua/UJRN/Nvmdups 2012229630 . [in Ukrainian].

4. Lozovetska, V. T. (2014). Kontseptualni zasady profesiinoho samorozvytku suchasnoi osobystosti [Conceptual principles of professional self-development of modern personality]. Scientific Bulletin of the Institute of Vocational Education of the National Academy of Pedagogical Sciences of Ukraine. Professional pedagogy. No. 1.pp. 33-39. [in Ukrainian]

5. Ministerstvo osvity i nauky Ukrainy (2016). [The concept of the "New Ukrainian School"]. Available at: https://mon.gov.ua/storage/app/media/ zagalna\%20serednya/nova-ukrainska-shkolacompressed.pdf/. [in Ukrainian].

6. Polozhennia pro tsentr profesiinoho rozvytku pedahohichnykh pratsivnykiv [Regulations on the center of professional development of pedagogical workers]. Resolution of the Cabinet of Ministers of Ukraine. 29.07.2020 p. No. 672. Available at: https:// zakon.rada.gov.ua/laws/show/672-2020-\%D0\%BF\#n10/. [in Ukrainian].

7. Reiestr profesiinykh standartiv [Register of professional standards]. Website of the Ministry of Economy. 2021. Available at: https://www.me.gov.ua/ Documents/Detail?lang-uk-UA\&id=22469103-4e36-4d41b1bf-288338b3c7fa\&title=RestrProfesiinikhStandartiv/. [in Ukrainian].

8. Smoliuk, A. I. (2017). Teoretychna pidhotovka vchytelia pochatkovoi shkoly u formuvanni hotovnosti do profesiinoho samorozvytku [Theoretical training of primary school teachers in the formation of readiness for professional self-development]. Current issues of pedagogical education: European and national dimension. pp. 253-256. [in Ukrainian].

9. Familiarska, L.L. (2016). Neperervna osvita pedahoha: sutnist suchasnoi vzaiemodii v osvitnomu seredovyshchi [Continuing teacher education: the essence of modern interaction in the educational environment]. Current issues, problems and prospects for the development of humanitarian knowledge in the modern information space: national and international aspects: Coll. scientific works. pp. 200-202. Available at: https://core.ac.uk/ download/pdf/84594081.pdf\#page $=200 /$. [in Ukrainian].

10. Yamnytskyi, V. M.(2013). Zdatnist do samorehuliatsii yak osnova profesionalizatsii spetsialista. [Ability to selfregulation as a basis for professionalization of a specialist]. Psychology: reality and prospects. Vol. 1. pp. 26-29. [in Ukrainian].

Стаття надійшла до редакції 15.02.2021

\section{G58080

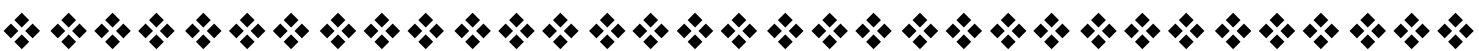

